\title{
An Analysis of the Obstacles to the Implementation of BIM in China's Project Cost
}

\author{
Lei Tian, Qiong Shen* and Yanan Ma \\ College of Architecture and Urban-Rural Planning, Sichuan Agricultural University, Dujiangyan \\ Sichuan, 611830, China
}

\begin{abstract}
BIM has huge potential in the construction industry, but the development in the field of project cost is not as good as expected. In this paper, the factors that prevention BIM implemented in project cost were sorted out, and the factors were graded by questionnaires, then factor analysis method and importance index were used to calculate the biggest influence factor of BIM in project cost. This paper puts forward some measures from the perspectives of personnel, software, cost and enterprises, such as strengthening cooperation between universities and enterprises to cultivate fine talents, increasing scientific research investment to perfect BIM cost software, enriching BIM learning resources to increase the study enthusiasm of cost workers, and establishing reasonable cost-sharing mode. In order to promote the development of project cost information in China.
\end{abstract}

Keywords: BIM, Project cost, Factor analysis, Obstacle factors

\section{Introduction}

Along with the progress of the whole construction industry, the project cost information has got certain development. The latest technologies have provided more possibility for the construction industry's benign development, among which BIM technology is particularly favored by everyone. It can be used in design, construction, management and so on. It has the advantages of visualization, coordination, simulation, optimization, integration, parameterization, information completeness and map-making. With the increasing demand for building quality, there is an increasing demand for BIM to be applied to building. Therefore, BIM3D and BIM4D technology were born. 4D is based on 3D technology, adding time management, and can control the progress of the project. Then, the BIM5D technology, which is beneficial to cost management, can be used to simulate the construction process by combining the building model, schedule and cost management with the BIM platform, and provide contract management information. So that the project can be in all stages of information sharing, saving time and cost.

Most researches on BIM in China remain at the analysis stage, lacking systematization and sufficient experience to support it. In order to implement BIM, the government has also formulated relevant policies. In August 2017, Ministry of Housing and Urban-rural Development issued the "13th five-year Plan" of the project cost, which proposes to

* Corresponding author: $\underline{\text { swydong@, sicau.edu.cn }}$ 
vigorously promote the application of BIM technology in project cost. However, there is still a long way to go to achieve the goal of integrating BIM with management systems and other information technologies. In order to speed up this process and realize the popularization of BIM in project cost as soon as possible, some scholars have studied the difficulties faced by the implementation of BIM. Gao et al. [1], Xu et al. [2] respectively used factor analysis, DEMATEL analysis and ISM analysis to study the influencing factors of the application of BIM in China's construction industry and corresponding countermeasures and suggestions were put forward. It provided reference for perfecting BIM application standard and promoting the popularization of BIM in China. Zheng et al. [3] indicated that enterprises should pay attention to both technical upgrading and teamwork to promote the application of BIM. Liu et al. [4], Xue et al. [5] focused on the cost process of BIM application barriers and the main problems in the proposed measures. so that the project cost can realize informatization as soon as possible. Zhu et al. [6] discussed the obstacles and system guarantee system of project cost information construction in order to put forward feasible suggestions for the reform of project cost consultation industry. The previous researches lack of BIM in the project cost implementation of barriers to explore the relationship between factors. So, this paper used factor analysis and importance index to calculate the degree of influence of the obstacles. Finally, some suggestions are given to solve the problem.

\section{Obstacles to the development of BIM in the cost industry}

In this paper, the existing adverse phenomena and relevant literature were analyzed, then some representative obstacles were sorted out. The obstacles were made into an expert questionnaire, and the personnel who have been engaged in relevant research or work for more than 3 years are consulted. The result is a list of 18 obstacles of BIM in the project cost, as Table 1. Factor analysis method and importance index were used to analyze the obstacles proposed and explore the relationship between them. The results obtained can provide targeted recommendations for the implementation of BIM in the project cost.

Table1. Obstacles to the implementation of BIM in the project cost.

\begin{tabular}{|c|c|c|c|c|c|}
\hline Code & Influence factor & $\begin{array}{l}\text { Common } \\
\text { factorV1 }\end{array}$ & $\begin{array}{l}\text { Common } \\
\text { factorV2 }\end{array}$ & $\begin{array}{l}\text { Common } \\
\text { factorV3 }\end{array}$ & $\begin{array}{l}\text { Common } \\
\text { factorV4 }\end{array}$ \\
\hline \multirow[t]{2}{*}{ F1 } & & 0.165 & 0.226 & 0.695 & 0.284 \\
\hline & BIM lack standard system & & & & \\
\hline $\mathrm{F} 2$ & $\begin{array}{l}\text { BIM in the project cost lack } \\
\text { overall management }\end{array}$ & 0.581 & 0.508 & 0.23 & 0.025 \\
\hline F3 & $\begin{array}{l}\text { BIM in the project cost raise } \\
\text { industry requirements }\end{array}$ & 0.692 & 0.148 & 0.219 & -0.088 \\
\hline F4 & $\begin{array}{l}\text { The publicity work of } \\
\text { promoting BIM application in } \\
\text { the project cost is not in place }\end{array}$ & 0.787 & 0.252 & 0.032 & 0.09 \\
\hline F5 & $\begin{array}{l}\text { The application of BIM in the } \\
\text { cost industry lacks professional } \\
\text { talents }\end{array}$ & 0.743 & 0.111 & 0.191 & 0.188 \\
\hline F6 & $\begin{array}{l}\text { The application of BIM in the } \\
\text { project cost government support } \\
\text { is insufficient }\end{array}$ & 0.402 & 0.299 & 0.503 & -0.289 \\
\hline
\end{tabular}




\begin{tabular}{|c|c|c|c|c|c|}
\hline F7 & $\begin{array}{l}\text { The application of BIM in the } \\
\text { project cost faces negative } \\
\text { treatment from enterprises }\end{array}$ & 0.572 & -0.134 & 0.315 & 0.514 \\
\hline F8 & $\begin{array}{l}\text { Software purchases and } \\
\text { hardware upgrades are } \\
\text { expensive }\end{array}$ & 0.733 & 0.123 & 0.097 & 0.338 \\
\hline F9 & $\begin{array}{l}\text { The project cost industry } \\
\text { information sharing is not } \\
\text { timely }\end{array}$ & 0.412 & 0.627 & 0.278 & 0.014 \\
\hline F10 & $\begin{array}{l}\text { BIM cases and practical } \\
\text { experience are relatively few }\end{array}$ & 0.378 & 0.525 & 0.336 & 0.15 \\
\hline F11 & $\begin{array}{l}\text { The industrial dispute } \\
\text { processing mechanism is not } \\
\text { perfect }\end{array}$ & 0.151 & 0.841 & 0.044 & 0.067 \\
\hline F12 & $\begin{array}{l}\text { The synergy ability of the } \\
\text { industry needs to be improved }\end{array}$ & 0.058 & 0.759 & 0.393 & 0.059 \\
\hline F13 & $\begin{array}{l}\text { BIM software is not fully } \\
\text { compatible with cost software }\end{array}$ & 0.119 & 0.524 & 0.12 & 0.607 \\
\hline F14 & $\begin{array}{l}\text { The work flow of the project } \\
\text { cost restricts the application of } \\
\text { BIM }\end{array}$ & 0.158 & 0.257 & 0.774 & 0.156 \\
\hline F15 & $\begin{array}{l}\text { The BIM models have unclear } \\
\text { intellectual property rights in its } \\
\text { cost application }\end{array}$ & 0.03 & 0.802 & 0.244 & -0.235 \\
\hline F16 & $\begin{array}{l}\text { The economic benefits brought } \\
\text { by BIM are not significant } \\
\text { enough }\end{array}$ & 0.342 & -0.03 & 0.195 & 0.702 \\
\hline F17 & $\begin{array}{l}\text { The cost of personnel training is } \\
\text { high }\end{array}$ & 0.743 & 0.054 & 0.03 & 0.395 \\
\hline F18 & $\begin{array}{l}\text { Lack of testing methods for } \\
\text { accuracy of BIM models for } \\
\text { cost work }\end{array}$ & 0.123 & 0.718 & -0.019 & 0.471 \\
\hline
\end{tabular}

\section{Research methods}

\subsection{Questionnaires design and distribution}

The survey was designed using a 5-level Likert scale to rate the obstacles to BIM implementation in terms of project cost. Questionnaires distributed in the range of Chengdu and Chongqing, two cities, and the issuance of the questionnaires cover the design, construction, and real estate industry. The issuance of the questionnaires mainly adopts two ways: through the individual distributed, construction industry workers and construction cost workers were investigated; Through the instructor to carry out the questionnaires, most of the respondents served as a project manager or technical director of the project. A total of 120 questionnaires were issued in this survey, and 98 valid questionnaires were recovered, with the effective questionnaires recovery rate of $81.7 \%$. Among them, there are 69 
questionnaires from relevant employees and 29 questionnaires from graduate students and tutors of relevant majors in universities.

\subsection{Data processing}

Questionnaire reliability test. Reliability is to test the validity of statistical data, and Cronbach's A is generally used as the index of reliability test. Usually, Cranbach's A above 0.6 indicates reliable statistical data. In this paper, the coefficient of Cranbach's A is 0.908 through Spss25.0 calculation, indicating that the survey data credibility of the questionnaires is good.

To extract the key factors. The significance coefficient of KMO value and spherical test is used to judge whether the original factor indicator variable is suitable for factor analysis. If the KMO value is greater than 0.5 , it indicates that there is a high correlation between the original factor indicator variables and it is suitable for factor analysis. In sphericity test, if the significance coefficient is less than 0.05 , it is appropriate to carry out factor analysis on the original factor indicator variable. According to Spss25.0 calculation in this study, KMO value was 0.801 greater than 0.5 , and Sig value was 0.000 , less than 0.05 . So the survey data were suitable for factor analysis. In this study, principal component analysis was used for factor analysis of original factor variables, and factors with eigenvalues greater than or equal to 1 were selected as key factors. Through calculation, 4 common factors were extracted, and the cumulative variance contribution rate was $67.067 \%$, which was more than $60 \%$, indicating that these four factors could summarize most of the information of the 18 factors. At the same time, orthogonal rotation of the factor component matrix was performed by the maximum variance rotation method. The rotated factor component matrix was shown in Table 1. The maximum factor loading value of each initial variable relative to each principal component is found in the rotated factor component matrix (bold numbers in Table 1) and merged into the common factor.

As Table 1, the 18 questionnaire indicators are divided into 4 common components. Common component V1 include: F2、F3、F4、F5、F7、F8、F17, and it was named as industry influence factors. Common component V2 include: F9、F10、F11、F12、F15、 F18, and it was named as environmental influence factors. The common component V3 includes: F1 VF6、F14, and it was named as system influencing factors. Common component V4 includes: F13、F16, and it was named as software influencing factors.

\subsection{The importance of calculating key obstacle factors}

The importance index of key obstacle factors is calculated, using the following formula:

$$
\frac{\left(\mathrm{a}_{1} \mathrm{~m}_{1}+\mathrm{a}_{2} \mathrm{~m}_{2}+\mathrm{K}+\mathrm{anm}_{\mathrm{n}}\right)}{98} \times \frac{100}{5}
$$

$a_{n}$ is in the score of the $n$th obstacle factor index; $m_{n}$ is the number of questionnaires with the same score for the nth obstacle index. The calculation results are shown in Table 2. 
Table 2. Importance calculation table.

\begin{tabular}{|c|c|c|c|c|c|c|}
\hline Module & $\begin{array}{l}\text { Common } \\
\text { factor }\end{array}$ & $\begin{array}{l}\text { Importance } \\
\text { index }\end{array}$ & Ranking & $\begin{array}{l}\text { Obstacle } \\
\text { factor }\end{array}$ & $\begin{array}{l}\text { Importance } \\
\text { index }\end{array}$ & $\begin{array}{c}\text { Rankin } \\
\mathrm{g}\end{array}$ \\
\hline \multirow{7}{*}{$\begin{array}{c}\text { industry } \\
\text { influencing factors }\end{array}$} & \multirow[t]{7}{*}{ V1 } & \multirow[t]{7}{*}{81.14} & \multirow[t]{7}{*}{1} & F2 & 74.29 & 10 \\
\hline & & & & F3 & 74.49 & 9 \\
\hline & & & & F4 & 74.29 & 10 \\
\hline & & & & F5 & 89.39 & 1 \\
\hline & & & & F7 & 83.67 & 4 \\
\hline & & & & F8 & 87.35 & 2 \\
\hline & & & & F17 & 84.49 & 3 \\
\hline \multirow{5}{*}{$\begin{array}{c}\text { environmental } \\
\text { influencing factors }\end{array}$} & \multirow[t]{5}{*}{ V2 } & \multirow[t]{5}{*}{67.21} & \multirow[t]{6}{*}{4} & F9 & 74.08 & 12 \\
\hline & & & & F10 & 77.96 & 7 \\
\hline & & & & F11 & 61.43 & 17 \\
\hline & & & & F12 & 62.86 & 16 \\
\hline & & & & F15 & 59.8 & 18 \\
\hline \multirow{4}{*}{$\begin{array}{l}\text { system influencing } \\
\text { factors }\end{array}$} & \multirow{3}{*}{ V3 } & \multirow{3}{*}{74.56} & & F18 & 67.14 & 15 \\
\hline & & & \multirow[t]{3}{*}{3} & F1 & 77.14 & 8 \\
\hline & & & & F6 & 72.86 & 14 \\
\hline & \multirow{3}{*}{ V4 } & \multirow{3}{*}{79.9} & & F14 & 73.67 & 13 \\
\hline \multirow{2}{*}{$\begin{array}{c}\text { software } \\
\text { influencing factors }\end{array}$} & & & \multirow[t]{2}{*}{2} & F13 & 80 & 5 \\
\hline & & & & F16 & 79.8 & 6 \\
\hline
\end{tabular}

From Table 2, industry influence factors play an important role in the promotion of BIM in the project cost, among which the lack of professional talents is the biggest obstacle for BIM to be used in the project cost. The high cost of software purchases, hardware upgrade and personnel training and the application of BIM in the project cost faces negative treatment from enterprises also have great impact. To promote the popularization of BIM in the project cost, we need to solve the outstanding problems, and then gradually promote the in-depth application of BIM in the project cost.

\section{Suggestions}

Through the above researches, in order to better develop BIM in the project cost, the following suggestions are put forward:

(1) Paying attention to the cultivation of fine talents. The shortage of professional refined talents is an urgent problem to be solved at present, which requires the cost talents not only to master the specifications of engineering quantity calculation, but also to be skilled in modeling software. Furthermore, they also need to know how to use resources to reduce costs and complete real-time dynamic cost management to achieve process control. For the cultivation of the talents can adopt the way of cooperation between colleges and enterprises. The school adjusts the student development plan according to the needs of the enterprise. Enterprises provide more resources and technology for schools, which can help schools deepen education. Through this way, the software operation ability and practical application 
ability of the relevant employees can be improved, and the whole process of cost management can be refined.

(2) Increase the investment in BIM research and improving the functions of cost software. At present, most of the BIM software in our country's cost industry is imported from abroad, and the statistical rules of software embedding in foreign countries are not completely unified with the rules of domestic engineering quantity calculation, therefore, it is inevitable that due to the applicability problem, the software functions are missing or the application effect is not ideal. The introduction and maintenance of BIM related cost software as well as the hardware upgrades cost of enterprises are all relatively high, which lead to the low popularity of BIM software application in the domestic project cost consulting industry. Therefore, to promote BIM in the cost industry, the research and development department needs to localize BIM software, improve software compatibility, reduce software requirements, and reduce software costs. In order to promote the application of BIM software in the cost industry and improve the information level of the cost industry.

(3) Enriching BIM learning resources and enhancing the enthusiasm of cost personnel in independent learning. At present, there is a shortage of BIM cost personnel with strong learning ability and rich practical experience in China, and even less BIM experts who can provide training and guidance for project cost personnel, which invisibly increases the difficulty of BIM learning. In addition to spending a lot of time on software operation training, cost practitioners should accumulate experience through constant practice to become mature BIM cost personnel. In order to solve this problem, we need to lower the learning threshold of BIM, enrich the learning resources, organize the exchange of experience and discussion of BIM experts and technical staff at home and abroad, and formulate incentive policies. With the increase of the initiative of the cost personnel, the time and cost of training BIM cost personnel will be reduced.

(4) Improving the enthusiasm of the enterprise. Lack of BIM awareness among senior management is a common phenomenon in the current construction industry, and the cost and benefit of BIM application do not match for the enterprise. Both discourage managers from applying BIM. In the case of immature market rules and imperfect guidance standards, the owner holds a wait-and-see attitude towards the application of BIM in cost management by the cost consulting industry. Therefore, the government's formulation of incentive policies to provide guarantee is the basis for promoting the promotion of BIM in the construction cost industry in China. On this basis, the issue of cost distribution should also be considered. Cost distribution should be carried out according to all interested parties, to reduce the concerns of owners and enterprises and reduce obstacles for the implementation of BIM in the construction cost industry.

\section{Conclusion}

In this study, questionnaire survey and factor analysis were used to extract 4 common influencing factors of BIM application in the project cost. This paper puts forward some measures from the perspectives of personnel, software, cost and enterprises, such as strengthening cooperation between universities and enterprises to cultivate fine talents, increasing scientific research investment to perfect BIM cost software, enriching BIM learning resources to increase the study enthusiasm of cost workers, and establishing reasonable cost-sharing mode. They provide solutions to the outstanding problems that BIM faces in the development and popularization of the project cost in China, and promote the development of project cost information in China. 


\section{References}

1. M. Gao, S.Y. Hao, A Study of Influencing Factors for BIM Application in Chinese Construction Industry Based on Factor Analysis, J Engin Mgt, 33(4), 38-42(2019).

2. Y.Q. Xu, Y.Y. Kong, Analysis of the Influence Factors of Application and Promotion of BIM in China, J Engin Mgt, 30(2), 28-32 (2016).

3. Y.J. Zheng, X. Ma, Y.Z. Su, T. Li, Y. Zhang, P. Lu, Research on Barriers of BIM Application in Construction Enterprises - Based on Literature Review Method, J Info Tech Civ Engin Arch, 11(5), 61-65(2019).

4. C. Liu, J. J. Guo, Study on Barriers of Building Information Modeling in the Process of Cost, J Engin Mgt, 30(2), 33-38(2016).

5. D. Xue, Research on application barriers of BIM in the cost process, Tech Econ Gui, 26(3)206-208(2018).

6. X.S. Zhu, J.P. Peng, Barriers and Institutional Security System of China's Project Cost Information Construction, J Engin Mgt, 29(2), 22-26(2015). 